\title{
QUA VADIS INDEPENDENSI ADVOKAT DALAM SISTEM PERADILAN DI INDONESIA
}

\author{
Solehuddin \\ Fakultas Hukum Universitas Bhayangkara Surabaya \\ e-mail: @gmail.com
}

\begin{abstract}
ABASTRAK
Advokat adalah sebuah profesi terhormat (offiem nobile). Dalam konteks penegakan hukum, advokat merupakan bagian yang mutlak harus ada dalam menjalankan tugas dan profesinya demi tegaknya keadilan berdasarkan hukum untuk kepentingan masyarakat pencari keadilan (justhbelem). Sebuah fungsi yang sangat pokok dalam proses pencarian jati diri negara hukum Indonesia.
\end{abstract}

Kata Kunci: Quo vadis, Independensi, Advokat, sistem peradilan

\section{ABSTRACT}

Advocate is an honorable profession (offiem nobile, or main). In the context of law enforcement, advocate is the part that absolutely must have in carrying out its duties and profession for the sake of justice under the law for the public interest justice seekers (justhbelem). A very basic function in the search process identity of Indonesian law.

Keywords: Quo vadis, Independence, Advocate, the judicial system

\section{PENDAHULUAN}

Salah satu tuntutan reformasi sejak tahun 1998 di Indonesia, untuk mengatasi krisis multi dimensi adalah mereformasi hukum yang terfokus pada masalah penegakan hukum. Namun sangat disayangkan setelah sepuluh tahun reformasi berlalu hingga kini masalah penegakan hukum belum juga menampakkan hasil yang signifikan sesuai tujuannya yaitu menciptakan masyarakat yang sejahtera, adil dan makmur sebagaimana yang dicita-citakan dalam proklamasi 1945. Berlarutlarutnya penyelesaian krisis multi dimensi salah satunya disebabkan oleh terjadinya kekacauan hukum (judicial disarray) yang menuntut untuk segera dilakukan reformasi dalam bidang hukum dengan melakukan perubahan dan pembaharuan total terhadap seluruh sistem hukum (legal system) dan penegakan hukum (law enforcement), terutama terhadap lembaga dan aparat penegak hukum kita seperti hakim, jaksa, polisi dan advokat. (Pasal 1 Butir 1 dan 2 UU No. 18 Tahun 2003).

Sebagai konsekuensi adanya reformasi tersebut telah terjadi beberapa kali perubahan terhadap UUD 1945 (1999-2002) yang membawa perubahan besar dalam sistem ketatanegaraan Indonesia, baik dalam pelembagaan kekuasaan legislatif, eksekutif, maupun yudisial (kekuasaan kehakiman). Berbagai persoalan yang membelit eksistensi kekuasaan kehakiman sebagaimana dipaparkan di atas menjadi salah satu agenda penting reformasi, sehingga pada perubahan UUD 1945, (Abd. Mukhtie Fadjar, 2009: 26), Pasal-pasal yang mengatur tentang kekuasaan kehakiman mengalami perubahan yang cukup signifikan.

Akibat dari perubahan pengaturan kekuasaan kehakiman dalam UUD 1945, maka telah dikeluarkan beberapa undang-undang yang terkait dengan kekuasaan kehakiman salah satunya adalah UU No. 18 tahun 2003 Tentang Advokat. (Abd. Mukhtie Fadjar, 2009: 26)

Salah satu lembaga yang memiliki peranan yang sangat urgen dan mutlak diperlukan dalam struktur negara modern dan mewadahi salah satu komponen dalam negara hukum adalah kekuasaan kehakiman yang bebas, mandiri dan bertanggung jawab. Kekuasaan kehakiman berfungsi sebagai lembaga pengontrol terhadap pelaksanaan hukum dalam negara hukum. Sedemikian pentingnya lembaga kontrol terhadap berlakunya hukum ini sehingga mutlak diperlukan suatu lembaga kekuasaan kehakiman yang tidak hanya sekedar ada, memiliki fasilitas yang diperlukan, mampu menyelesaikan perkara yang muncul, namun lebih dari itu juga harus bersyaratkan sebuah predikat yang bersih dan berwibawa dalam rangka untuk mewujudkan penegakan hukum dan keadilan. (Al Wisnobroto, 1997: 64).

Kekuasaan kehakiman yang bebas dari segala campur tangan dan pengaruh dari luar, memerlukan profesi advokat. Profesi advokat adalah profesi 
yang bebas, mandiri, dan bertanggung jawab, untuk terselenggaranya suatu peradilan yang jujur, adil, dan memiliki kepastian hukum bagi semua pencari keadilan dalam menegakkan hukum, kebenaran, keadilan, dan hak asasi manusia.

Tantangan besar yang terus membayangi perkembangan advokat di Indonesia adalah upaya menempatkan kedudukan, fungsi dan kewenangan advokat yang tepat dalam interaksinya dengan masyarakat maupun negara. Idealnya dalam hubungan timbal balik tersebut masyarakat akan memberikan legitimasi berupa kepercayaan atas janji publik yang dinyatakan advokat dalam mengupayakan kepastian, keadilan dan kemanfaatan. Sementara di sisi lain, negara akan memastikan terjaminnya kepentingan masyarakat dalam menyelenggarakan sistem peradilan, yang juga berarti menyediakan yurisdiksi bagi advokat agar mampu memenuhi janjinya kepada publik. (Binziad Kadafi, 2002: 1)

Dalam negara hukum, keberadaan, kedudukan, fungsi dan kewenangan advokat diperlukan dalam hubungannya dengan proses penegakan hukum, termasuk ikut andil dalam menjamin hak seseorang yang perlu diperhatikan dan agar tidak diabaikan, sehingga seseorang yang dituntut pidana atau digugat berhak dan dapat didampingi advokat agar kepentingannya dapat dibela secara yuridis dengan memperhatikan hak-hak azasinya. (Frans Hendra Winata, 1995: 26). Melalui jasa hukum yang diberikan, Advokat menjalankan tugas profesinya demi tegaknya keadilan berdasarkan hukum untuk kepentingan masyarakat pencari keadilan, termasuk usaha memberdayakan masyarakat dalam menyadari hak-hak fundamental mereka di depan hukum. Advokat sebagai salah satu unsur sistem peradilan merupakan salah satu pilar dalam menegakkan supremasi hukum dan hak asasi manusia.

Keberadaan advokat di Indonesia diawali sejak zaman Kolonial (Hindia Belanda), Revolusi Kemerdekaan, Demokrasi Terpimpin, Orde Baru, hing-ga sekarang ini. Sebagaimana halnya di tanah jajahan lainnya, keadvokatan Indonesia memiliki bentuk tidak seperti Advokat yang berasal dari orang-orang Belanda dan tidak sepenuhnya absah da-lam perhatian penjajahan Belanda. Pengaturan advokat pada pemerintahan kolonial dititik beratkan pada peranan kehendak eksekutif bukan kehendak hukum itu sendiri, hal ini merupakan monopoli bagi pemerintahan Hindia Belanda yang memberi sedikit gerak bagi tumbuhnya advokat pribumi. Advokat
Indonesia yang pertama adalah Mr. Besar Marto Kusumo yang masuk dalan Rechthoceshool tahun 1909. (Daniel S Lev, 2000: 325-330).

Advokat adalah sebuah profesi terhormat (officum nobile) yang dalam menjalankan profesinya berada di bawah perlindungan hukum, undang-undang dan kode etik, memiliki kebebasan yang didasarkan kepada kehormatan dan kepribadian Advokat yang berpegang teguh kepada kemandirian, kejujuran, kerahasiaan dan keterbukaan. Advokat selaku penegak hukum sejajar dengan penegak hukum lain seperti jaksa, polisi, maupun hakim di dalam menjunjung tinggi supremasi hukum, oleh karena itu satu sama lainnya harus saling menghargai antara teman sejawat dan juga antara penegak hukum lainnya

Advokat sebagai unsur aparat penegak hukum di Indonesia peranan tidak perlu lagi diragukan, baik pada masa sebelum ataupun sesudah Indonesia merdeka. Perjalanan sejarah Advokat yang panjang di Indonesia telah membuktikan bahwa advokat telah memainkan perannya yang tidak kecil dalam mewujudkan penegakan hukum yang adil dan berwibawa, kendatipun sebelum era reformasi, bila dilihat dari dasar hukum yang ada, keberadaan Advokat belum diatur secara khusus, karena masih tersebar dalam berbagai peraturan perundangundangan, baik yang dikeluarkan pada masa Hindia Belanda maupun yang dikeluarkan oleh pemerintahan Indonesia.

Lev dalam sebuah essainya dengan jelas mendiskripsikan dan menganalisis proses mengonstruksi (pencarian) bentuk negara hukum di Indonesia sejak 1945. (Daniel S Lev; 2000:334) Menurut Lev, Advokat LBH berperan penting dalam proses pencarian jati diri negara hukum di Indonesia, terutama sejak tahun 1970-an yang disponsori Peradin (Persatuan Advokat Indonesia).

Lev menyatakan :

Private lawyers are a particularly impotant group in the history of cnstitutionalism, not because they are responsible for it or even all that essential to its evolution, but because they became the most articulate rationalizer of constitutionalist idea, in which they have a direct interest.

Analisis yang diajukan Lev tersebut masih relevan hingga sekarang. Saat demokrasi terpimpin 1960 an, advokat profesional terkena dampaknya baik secara ekonomis maupun ideologis. Di era itu, para advokat profesional membela kepentingan kliennya yang berseberangan dengan Soekarno, 
kalangan jurist sebagai kelompok yang tidak bisa turut serta berevolusi sehingga sah kiranya untuk diintervensi. Proses campur tangan Soekarno di ranah peradilan terjadi sangat sistematis dengan bukti dibolehkannya kasus tertentu. Ini dijamin dalam Pasal 19 UU no. 19 tahun 1964 tentang Ketentuan-ketentuan Pokok Kekuasaan Kehakiman. (Patra M. Zen, 2008: 36)

Lepas dari rezim Soekarno tak berarti membuat advokat jadi makin bebas dan perannya pada pembaharuan hukum makin besar. Kontribusinya justru menurun seiring pertumbuhan ekonomi dan kenaikan pendapatannya. Kontribusi advokat profesional dalam gerakan pembaharuan hukum juga disebabkan "lepasnya" LBH dari Peradin pada awal 1980-an, dengan terbentuknya Yayasan LBH Indonesia, serta adanya perpecahan organisasi advokat di Indonesia.

Dalam perkembangannya setelah diundangkannya Undang-Undang No. 18 tahun 2003 tentang Advokat, organisasi advokat masih terjadi perpecahan yaitu antara Perhimpunan Advokat Indonesia (PERADI) dan Kongres Advokat Indonesia (KAI), dimana kedua-duanya mengklaim bahwa PERADI merupakan satu-satunnya wadah tunggal dari organisasi Advokat Indonesia, begitu juga sebaliknya KAI juga menganggap sebagai organisasi Advokat yang diamanatkan oleh UU No. 18 tahun 2003. Meskipun dalam organisasi advokat tersebut mengalami perpecahan, jangan sampai perpecahan tersebut membawa dampak yang nigatif terhadap sistem penegakan hukum di Indonesia. Pengaturan Advokat dalam undang-undang diharapkan dapat memberikan dan meningkatkan citra profesi advokat dan menambah wibawa hukum (authority of law) dan supremasi hukum (supremacy of law) semakin ditegakkan. Apalagi advokat di dalam menjalankan tugas profesinya untuk membela perkara yang menjadi tanggung jawabnya dengan tetap berpegang pada kode etik profesi dan peraturan perundang-undangan. Disisi lain undang-undang advokat menjamin adanya hak kekebalan hukum (imunity) terhadap advokat didalam menjalankan tugas dan fungsinya untuk membela kliennya. (Pasal 16 UU No. 18 Tahun 2003)

Kebebasan profesi Advokat bersifat universal dan diakui oleh banyak negara terutama di negaranegara demokratis. Dengan adanya kebebasan profesi advokat, maka advokat dapat membela masyarakat (public defender) dan memperjuangkan kepentingan masyarakat tanpa rasa takut, campur tangan, dan tekanan dari pihak manapun juga. Kebebasan profesi advokat atau yang secara internasional dikenal dengan independence of the legal profession merupakan syarat mutlak terciptanya suatu peradilan bebas dan tidak memihak (independent and Impartial Judiciary), dengan tetap menjaga etik profesi. Masyarakat pada hakekatnya senantiasa mencari dan membutuhkan jasa hukum (legal services) dan pembelaan (ligition) dari advokat, sebab advokatlah yang merupakan orang yang bisa mewakili kepentingan masyarakat di depan hukum.

Fungsi dan Kewenangan Advokat Dalam Sistem Penegakan Hukum di Indonesia Fungsi yang dalam Kamus Besar Bahasa Indonesia diartikan sebagai pekerjaan yang dilakukan. (W.J.S Poerwadarminta; 1987:283) Fungsi dalam bahasa Inggris yaitu "function" yang didefinisikan sebagai "the kind of action or activity proper to any person or thing; atau the purpose for which samething is designed or exist; atau rule" Berdasarkan definisi tersebut fungsi adalah apa saja kegiatan yang dilakukan, atau sesuatu tujuan untuk mewujudkan rencana fungsi juga dapat diartikan sebagi peranan". (Talizuduhu Ndraha, 2005: 57)

Seorang sosiolog Levinson mengungkapkan bahwa sesungguhnya fungsi sangat dekat maknanya dengan peranan. Seseorang melaksanakan hak dan kewajiban sesuai dengan kedudukannya maka itulah menjalankan peranan. Dengan demikian, maka peranan sesungguhnya lebih banyak menunjuk pada fungsi. Fungsi paling tidak mencakup tiga hal, yaitu; (Lewisb A. Coser and Bernard Rosenberg, 1976)

Fungsi meliputi norma-norma yang dihubungkan dengan posisi atau tempat seseorang dalam masyarakat, fungsi dalam arti ini merupakan rangkaian peraturan yang membimbing seseorang dalam kehidupan kemasyarakatan; (a) Fungsi adalah suatu konsep perihal apa yang dapat dilakukan oleh individu/kelompok dalam masyarakat sebagai organisasi; (b) Fungsi juga dapat dikatakan sebagai prikelakuan individu yang penting bagi struktur sosial

Dengan demikian dikaitkan dengan fungsi Advokat dalam sistim peradilan di Indonesia, diharapkan advokat dalam menjalankan fungsinya harus tetap berpegang teguh pada peraturan perundang-undangan dan kode etiknya. Fungsi advokat untuk membela klien adalah menegakkan 
"Azas praduga tak bersalah (Presumption of Innocence)" yang dianut dalam sistem hukum kita atau Internasional Covenant on Civil and Political Rights, khususnya pasal 14 (2): "Everyone charged with a criminal offence shall have the right to be presumed innocent until proved guilty according to law" dan pasal 14 (3) menyebutkan:

"In the determination of eny criminal chrge againt him, everyone shal be antitled to the following minimum guarantee, in full equality: (a) To be informed promptly and in a langguage which he understands of the nature and cause of the charge again him; (b) To have adequate time and facilities for the preparation of his defence and to communicacate with coucel of his own choosing; (c) To be tried without undue delay; (d) To be tried in his presence and to defend himself in person or through legal assistance of hi own choosing, to be informed if he daes assigned to him, in any case where the interes of justice so require, and without payment by him in any such case if he does not have suffient means to pay for it; (e) To examine, or have examination of witnesses on his behalf under the same conditions as witnesses againt him: (f) To have the free assistanc of on interpreter if he can not understand or speak the langguage or speak the langguage uswe in court; (g) No to be compelled to testify against himself or to confess guilt.

"In the World Conference of the Independence of Justice" yang diadakan di Montreal, Canada 5 s/d 10 Juni 1983 yang disponsori oleh PBB yang dirumuskan sebagai berikut: "A person qualified and authorized to practice before the cours and to advise and refresent his cliens in legal matter". Berdasaarkan hasil Dekrarasi Montreal tersebut hak dan kewajiban advokat dirumuskan sebagai berikut: "lawyers shall anjoy fredom of belief, express-siona, asociation and asembly, and in particular they shall have the right to: (a) Take part in public discussion of matters conceerning the law and the administration of justice; (b) Join or formfreely local, national and international organization; (c) Propose and re commend well considered law reforms in the publik interes and inform the public about such matters; and (d) Take full and active part in political, social and cultural life of their country. The duties of a lawyer to wards his clients include;(a) Advising the client as to his legal rights and obligations. (b) Taking legal action to protect him ang his interest, and where required; (c) Respresenting him before caourt, tribunals or administrative authorities.

Dilihat secara teori dan konsepsi, dalam sistem kemandirian penegakan hukum di antara aparat penegak hukum yang paling mandiri (indevendency) adalah kekuasaan kehakiman (yudiciary power) dan Advokat (Lawyer). (Henry Camplell Black ,1991: 614) Perbedaannya bahwa Peran dan fungsi Advokat mewakili kepentingan masyarakat sedangkan polisi, jaksa dan hakim mewakili kepentingan negara dan pemerintah. Dengan demikian maka Advokat dituntut adanya profesionalisme yang tinggi di dalam menjalankan profesinya.

Adnan Buyung Nasution, mengungkapkan bahwa profesi advokat adalah free profesional; kebebasan profesi tidak sekedar demi profesi advokat itu sendiri, melainkan juga guna mewujudkan kepentingan yang lebih luas, yaitu terciptanya lembaga peradilan yang bebas; independen judiciary yang merupakan prasyarat dalam menegakkan rule of law dan melaksanakan nilai-nilai demokrasi. (Frans Hendra Winata, 1995: 14)

Menurut Chaeruman Harahap setidaknya mencatat sejumlah hambatan penegakan supremasi hukum di antaranya (Chaeruman Harahap, 2003: 24); (1) Belum sempurnanya perangkat hukum, (2) Masih rendahnya integritas moral aparat penegak hukum, (3) Penegak hukum belum profesional (kecakapan, keterampilan dan intelektualitas rendah), (4) Penghasilan aparat penegak hukum rendah, (5) Masih rendahnya tingkat kesadaran hukum masyarakat, (6) Kurangnya sarana dan prasarana, (7) Terjadinya campur tangan pemerintah dalam proses peradilan.

Advokat adalah salah satu penegak hukum sehingga diperlukan adanya integritas dan profesionalisme dalam menjalankan profesinya, sehingga hambatan dalam penegakan supremasi hukum dapat diatasi. Untuk menjaga citra dan kewibawaan advokat adalah salah satu fungsi dari sebuah organisasi advokat (bar association). Fungsi ini terkait erat dengan peran organisasi advokat untuk menjamin kualitas pelayanan yang diberikan kepada publik. Kemudian fungsi-fungsi tersebut dijabarkan dalam aturan-aturan tentang etika profesi advokat yang terdiri dari sejumlah asas (canons), aturan tentang tanggung jawab dan standart kerja profesi (professional responsibilities and standards of work), serta aturan penegakan disiplin (disciplinary proceedings). Untuk melihat 
etika profesi advokat yang mengatur kewajiban para anggota profesi advokat terhadap masyarakat, pengadilan, sejawat profesi, dan para kliennya.

Oleh karena peran dan fungsi advokat sebagai aparat penegak hukum sangat strategis melahirkan kondisi profesi yang rentan dari berbagai intervensi kepentingan, dan longgarnya profesi dari ikatan kepercayaan, dan tentu saja, pegawasan masyarakat. Dengan kata lain, kompleksitas persoalan yang menandai sejarah, kondisi empirik, dan kekuasaan negara yang menaunginya, juga diperburuk oleh cara pandang advokat dalam memahami letak profesi mereka. (Binziad Kadafi, 2002: 2)

Aneka macam fungsi yang melekat pada individu atau kelompok dalam masyarakat diharapakan harus dapat memperhatikan hal-hal sebagai berikut: (Binziad Kadafi, 2002: 2) (a) Fungsi-fungsi tertentu harus dilaksanakan apabila struktur masyarakat hendak dipertahankan kelangsungannya; (b) Fungsi tersebut seyogyanya diletakkan pada individuindividu atau kelompok yang oleh masyarakat dianggap mampu untuk melaksanakan; (c)Kadangkadang dalam masyarakat dijumpai mereka atau kelompok-kelompok yang tidak mampu menjalankan fungsinya karena dalam menjalankan fungsi seringkali penuh dengan pengorbanan; (d) Apabila mereka mampu dan sanggup menjalankan fungsinya, seringkali juga masyarakat tidak memberikan kesempatan atau peluang yang seimbang dAlam melaksanakan fungsinya.

Selanjutnya Sjachran Basah mengemukakan bahwa fungsi menurut Natuur-wissenchaft mempunyai empat arti, Sedangkan dalam Geisteswissenchaft mempunyai tiga arti; (a) fungsi berarti tergantung pada (pengertian pertama dari Natuurwissenschaft); (b) fungsi berarti tugas atau ambtwerking in het verband met het geheel (arti kedua dari Natuurwissenscaft dan arti pertama dari Geisteswissenschaft); (c) fungsi berarti hubungan timbal balik antara bagian dan keseluruhan (arti ketiga dari natuurwissenschaft) dan arti kedua dari Geisteswissenschaft (D) fungsi berarti werking (arti keempat dari Natuur-wissenschaft). (Hinca Panjaitan, 2001: 408)

Pengertian fungsi yang dilansir oleh Sjachran Basah itu, jika dipilah antara pengertian yang dirumuskan dalam Naturwissenschaft dan Geistes wissenchaft dapat dikelompokkan sebagai berikut:

(1) Dalam Natuurwissenscaft, pengertian fungsi;

(a) tergantung pada pengertian natuurwissenschaft;

(b) tugas, ambtworking in het verband met het geheel; (c) hubungan timbal balik antara bagian dan keseluruhan. (2) Dalam Geisteswissenschaft (a) fungsi berarti tugas, ambtwerking in het verband met het geheel; (b) fungsi berarti hubungan timbal balik antara bagian dan keseluruhan; (c) fungsi berarti pekerjaan (working). (Sajiono, 2008: 129)

Dilihat dari beberapa definisi tersebut dapat dimaknai bahwa fungsi merupakan suatu kegiatan atau aktifitas yang berkaitan dengan tugas pokok yang wajib dilaksanakan. Tugas pokok yang dilaksanakan tersebut, adalah untuk mencapai tujuan (goal) dari suatu organisasi. (Sajiono, 2008: 129)

Pengertian kata fungsi ini "masih belum bermakna apabila belum diikuti oleh kata lain. Artinya kata fungsi baru menampakkan arti yang benar jika dihubungkan dengan sesuatu masalah". (Hinca Panjaitan, 2001: 408) Dalam kajian ini fungsi dikaitkan dengan Advokat sehingga fungsi mempunyai makna tugas pokok yang wajib dilaksanakan oleh advokat dalam sistem peradilan di Indonesia.

Advokat dalam menjalankan fungsinya tidak disediakan anggaran oleh pemerintah. Karena orgaisasi advokat ini adalah organisasi non pemerintah, organisasi advokat adalah organisasi yang bebas dan mandiri yang dibentuk sesuai dengan ketentuan undang-undang ini dengan maksud dan tujuan untuk meningkatkan kualitas profesi advokat.

Ruang lingkup kerja Advokat modern memperlihatkan adanya fungsi Advokat dalam dua aspek, yaitu untuk (1) Mewakili klien di muka Pengadilan; Fungsi mewakili klien di muka Pengadilan merupakan hal yang klasik, yang keberadaannya sudah ada sejak lahirnya profesi tersebut dalam wilayah kekuasaan Pengadilan untuk mewakili kliennya. (2) Mewakili klien di luar Pengadilan. Fungsi mewakili klien di luar Pengadilan merupakan fungsi Advokasi yang berkembang seiring dengan makin kompleksnya hubungan masyarakat. (Hinca Panjaitan, 2001: 408)

Pada perkembangan kekinian, fungsi advokat dihadapkan pada tuntutan untuk lebih komprehensif dalam melaksanakan tugas dan kewajibannya, sehingga atas fungsi tersebut diperlukan adanya fungsi lain sebagai aspek ketiga, yaitu: untuk memberikan pencerahan di bidang hukum di tengah-tengah masyarakat, sehingga masyarakat "melek" hukum. perlu diperhatikan dan agar tidak 
diabaikan.

Ketiga aspek dari fungsi advokat di dalam menjalankan profesinya tampaknya harus dilengkapi pula dengan wewenang yang diberikan oleh peraturan Undang-undang dan kode etiknya, sehingga dalam menjalankan profesinya seorang Advokat ada rambu-rambu yang harus diperhatikan dan tidak menabrak dan melampaui batasan-batasan kewenangannya dalam rangka menjalankan tugas dan fungsinya.

Ada dua fungsi advokat terhadap keadilan yang perlu mendapat perhatian yaitu pertama, Mewakili klien untuk menegakkan keadilan, dan peran advokat penting bagi klien yang diwakilinya, kedua, membantu klien, seseorang advokat mempertahankan legitimasi sistem peradilan dan fungsi advokat. (Darly Koehn, 2000: 158)

Wewenang atau kewenangan adalah padanan kata autority, yaitu the power of right delegated or given; the power to judge, act or command". Dari kata tersebut terbentuk kata sifat authoritative. Wareen B. Brown dan Deniss J. Morberg menulis bahwa penggunaan wewenang harus dapat dipertanggungjawabkan (Talizuduhu Ndraha, 2003: 85) dengan demikian wewenang terkait dengan tangggung jawab (responbility). Tanggung jawab berasal dari kata latin respons (us). Yang juga berkaitan dengan kata latin lainnya respondere, to respond, dan spondere, to pledge, promise. Respoinsible berarti" answerable or accountable, as for something within one,s power or control "Responbility berarti "The state or fact of being responsible, dan "a particular burden of obligation upon a person who is responsible". (Talizuduhu Ndraha, 2003: 87) Tanggung jawab (responbility) menunjukan sejauhmana seseorang pelaku terbukti mampu menjalankan tugas atau perintah yang diamanatkan.

Wewenang dimaksudkan sebagai "suatu hak yang telah ditetapkan dalam suatu tata tertib sosial untuk menetapkan kebijaksanaan, menentukan keputusan-keputusan mengenai masalah-masalah yang penting dan untuk menyelesaikan pertentangan pertentangan". (Soerjono Soekanto, 1977: 172) Apabila orang membicarakan tentang wewenang advokat maka yang dimaksudkannya adalah:

Hak yang dimiliki oleh advokat dan profesinya. Tekanannya adalah pada hak, dan bukan pada kekuasaannya. Dipandang dari sudut masyarakat, maka kekuasaan saja tanpa wewenang merupakan kekuatan yang tidak sah. Suatu kekuasaan harus mendapatkan pengakuan dan pengesahan dari masyarakat agar menjadi suatu wewenang.

Sehubungan dengan ini. Talcot Person mengemukakan bahwa otoritas merupakan suatu hak yang secara kelembagaan diakui untuk mempengaruhi tindakan-tindakan pihak-pihak lain, tanpa memperhatikan sikap-sikap pribadi mereka yang paling dekat ke arah pengaruh. Hal ini digunakan dengan memegang jabatan sebuah kantor atau status lain yang oleh masyarakat dianggap terbatas seperti orang tua, dokter, nabi. (Talcot Parson, tanpa tahun: 80) Untuk itu advokat dalam menjalankan profesinya perlu diberikan kewenangan-kewenangan berdasarkan peraturan perundang-undangan dan kode etiknya.

Kewenangan advokat dalam sistem peradilan Indonesia adalah bahwa advokat adalah merupakan aparat penegak hukum, bebas dan mandiri yang dijamin oleh hukum dan peraturan perundangundangan. Advokat bebas mengeluarkan pendapat atau pernyataan dalam membela perkara yang menjadi tanggung jawabnya di dalam sidang pengadilan dengan tetap berpegang pada kode etik profesi dan peraturan perundang-undangan.

Sehubungan dengan wewenang ini. Max Weber membedakannya menjadi beberapa bentuk yakni "wewenang kharismatis, tradisionil, dan rasionil (legal). (Soerjono Soekanto, 1977: 172)

Berdasarkan pembagian wewenang tersebut, sesungguhnya Advokat mempunyai wewenang rasional yang diatur dalam peraturan perundangundangan berupa kemampuan Advokat sebagai salah satu aparat penegak hukum yang mewakili kepentingan masyarakat. Pada posisi seperti ini peran advokat sangat penting, terutama di dalam menjaga keseimbangan di antara kepentingan negara, pemerintah dan masyarakat. Sedangkan Hakim, Jaksa, Polisi merupakan aparat penegak hukum yang masuk dalam lembaga yudikatif yang perannya ditempatkan dalam kepentingan negara, jaksa dan kepolisian mewakili kepentingan pemerintah.Independesi Advokat yang Unindependen Versus Advokat sebagai Profesi Terhormat (Officium Nobille).

Advokat adalah sebuah profesiterhormat (officum nobile) yang dalam menjalankan profesinya berada di bawah perlindungan hukum, undang-undang dan kode etik, memiliki kebebasan yang didasarkan kepada kehormatan dan kepribadian Advokat yang berpegang teguh kepada kemandirian, kejujuran, kerahasiaan dan keterbukaan. Advokat selaku 
penegak hukum sejajar dengan penegak hukum lain seperti jaksa, polisi, maupun hakim di dalam menjunjung tinggi supremasi hukum, oleh karena itu satu sama lainnya harus saling meng-hargai antara teman sejawat dan juga antara penegak hukum lainnya.

Advokat sebagai profesi terhormat harus menjaga kehormatan, keberanian, komitmen, integritas, dan profesional adalah ramuan dasar bagi seorang advokat. Sudah sejak dahulu kala, profesi advokat dianggap sebagai profesi mulia atau apa yang terkenal istilah nobille officium. Karena itu, dalam bersikap tindak, seorang advokat haruslah menghormati hukum dan keadilan, sesuai dengan kedudukan seorang advokat sebagai "the officer of the court". (Edi Krisharyanto, 2007) Akan Tetapi dalam kenyataannya, advokat merupakan profesi yang sangat dibenci masyarakat. Dalam drama William Shakespeare yang terkenal itu, yaitu: Lets jill all the lawyers (bunuh semua advokat), Para advokat tidak perlu marah jika profesi ini dikategorikan sebagai 'Profesi sampah". Tetapi sampah yang dicemburui. (M Taufik \& Moegono, 2007) Untuk menetralisir adanya stigma negatif dan kecemburuan di antara aparat penegak hukum yang lain terhadap profesi advokat diperlukan adanya payung hukum yang mengatur tentang keberadaan advokat yaitu UU No. 18 tahun 2003. Ada beberapa pasal dalam Undang-undang No. 18 tahun 2003 tentang Advokat yang mengatur tentang ke Independensian keberadaan advokat di dalam menjalankan profesinya diantaranya:

Pasal 1 ayat (1) "Advokat adalah orang yang berprofesi memberi jasa hukum, baik di dalam maupun di luar pengadilan yang memenuhi persyaratan berdasarkan ketentuan Undang-undang ini”.

Pasal 2 ayat (2) "Pengangkatan Advokat dilakukan oleh Organisasi Advokat"

Pasal 5 (1) "menyebutkan advokat berstatus sebagai penegak hukum, bebas dan mandiri yang dijamin oleh hukum dan peraturan perundangundangan".

Kedudukan advokat dalam kerangka negara hukum sangat penting dan strategis. Ia merupakan salah satu unsur penegak hukum, disamping penegak hukum yang lain, seperti Polisi, Jaksa, dan Hakim. Advokat diminta untuk selalu menjunjung tinggi nama baik, kehormatan, martabat dan citranya sebagai penegak hukum, kebenaran dan keadilan. Status tersebut hanya bisa di dapat oleh advokat bila dapat melaksanakan kode etik profesi dengan konsekwen dan konsisten. Di samping itu, selalu mempertinggi dan memperluas pengetahuan, kemampuan dan profesionalnya. (Edi Krisharyanto, 2007)

Advokat sebagai salah satu aparat penegak hukum yang mewakili kepentingan masyarakat. Pada posisi seperti ini peran advokat sangat penting, terutama di dalam menjaga keseimbangan diantara kepentingan negara, pemerintah dan masyarakat. Sedangkan Hakim, Jaksa, Polisi merupakan aparat penegak hukum yang masuk dalam lembaga yudikatif yang perannya ditempatkan dalam kepentingan negara, jaksa dan kepolisian mewakili kepentingan pemerintah.

Keberadaan advokat dalam sistem hukum kita mempunyai peran yang vital dan krusial karena advokat adalah subsistem dari sistem hukum kita. Advokatlah yang memiliki akses menegakkan hukum dan keadilan serta penghubung antara masyarakat dengan negara melalui institusi hukumnya. Oleh karena itu dalam menjalankan profesinya, Advokat harus bekerja atas dasar etika dan moralitas agar tidak terlibat dan menjadi bagian dari mafia peradilan dan judicial corruption.

Betapa pentingnya keberadaan advokat dalam sistem peradilan di Indonesia, karena Advokat dalam menjalankan profesinya bebas memasuki semua tahapan dalam proses penyelidikan, penyidikan kepolisian, kejaksaan dan pengadilan (perkara perdata, pidana, administrasi, perburuhan, persaingan usaha, dan sebagainya). Bahkan seorang advokat bisa memberikan nasihat dan bantuan hukum terhadap orang-orang yang mempunyai permasalahan hukum di luar proses peradilan (penyelesain non litigasi). Dengan demikian advokat sebagai aparat penegak hukum sangat berperan dalam menciptakan suatu kepastian, keadilan dan kemanfaatan hukum dalam sistem peradilan Indonesia.

Melihat kedudukan advokat yang sangat strategis dalam sistem peradilan di Indonesia diperlukan suatu organisasi yang kuat sebagai wadah bagi profesi Advokat dalam menjalankan profesinya. Pasal 28 ayat (1) UU No. 18 Tahun 2003 tentang Advokat, menyebutkan bahwa: Organisasi Advokat merupakan satu-satunya wadah profesi Advokat yang bebas dan mandiri yang dibentuk sesuai dengan ketentuan undang-undang ini dengan maksud dan tujuan untuk meningkatkan kualitas profesi Advokat. Oleh karena itu, organisasi 
Advokat pada dasarnya adalah organ negara dalam arti luas yang bersifat mandiri (independent state organ) yang juga melaksanakan fungsi negara.

Melihat ketentuan bunyi pasal-pasal tersebut di atas menunjukkan bahwa betapa independennya profesi Advokat dalam sistem peradilan di Indonesia. Keindependensian profesi advokat senada dengan keindependensian Peradilan itu sendiri. Keindependensian peradilan merupakan salah satu prinsip penting dalam negara demokrasi. Prinsif tersebut menghendaki agar lembaga peradilan termasuk Mahkamah Agung (MA) terbebas dari campur tangan, tekanan atau paksaan, baik langsung maupun tidak langsung dari kekuasaan lembaga lain, teman sejawat atau atasan, serta pihak-pihak lain di luar peradilan. Sehingga Hakim dalam memutus perkara hanya demi keadilan berdasarkan hukum dan hati nurani. (Shimon Shetreet, 1985) Oleh karena dalam lembaga peradilan memerlukan profesi advokat, maka profesi advokat juga harus independen.

Terwujudnya independensi profesi advokat diperlukan adanya jaminan dalam konstitusi atau peraturan perundang-undangan lainnya. Jaminan tersebut tidak cukup hanya sebatas kata-kata bahwa negara menjamin independensi profesi advokat, namun seluruh pengaturan mengenai bagaimana seorang advokat diangkat, disumpah dan diberhentikan harus diatur sedemikian rupa sehingga Advokat benar-benar merasa terjamin kebebasannya untuk menjalankan fungsinya.

Jika kita membaca bunyi Pasal 4 (1) UU No. 18 tahun 2003 menyebutkan bahwa sebelum menjalankan profesinya, advokat wajib bersumpah menurut agamanya atau berjanji dengan sungguh-sungguh di sidang terbuka Pengadilan Tinggi di wilayah domisili hukumnya". Dengan adanya kewajiban advokat bersumpah di sidang terbuka Pengadilan Tinggi sebelum mereka menjalankan profesinya, merupakan salah satu bentuk intervensinya lembaga peradilan dalam keindependensian profesi Advokat. Independensi profesi advokat telah ternodai dengan pengambilan sumpah tersebut.

Campur tangan lembaga peradilan dalam profesi advokat membuat organisasi advokat menjadi mandul dan fungsinya tidak optimal. Salah satu wujud adanya campur tangan lembaga peradilan dalam profesi Advokat adalah terbitnya surat tetanggal 1 Mei 2009 dari Mahkamah Agung kepada seluruh Pengadilan Tinggi di seluruh Indonesia untuk tidak melakukan penyumpahan terhadap para Advokat baru. Surat Mahkamah Agung yang ditujukan kepada Pengadilan Tinggi seluruh Indonesia tersebut berdampak sangat serius bagi perkembangan profesi advokat ke depan, karena para advokat yang telah lulus ujian baik ujian tersebut dilakukan oleh Perhimpunan Advokat Indonesia (PERADI) maupun Kongres Advokat Indonesia (KAI) tidak bisa menjalankan profesinya "tidak dapat berpraktek" untuk mendampingi atau membela masyarakat pencari keadilan di pengadilan. Meskipun surat Mahkamah Agung tersebut ditujukan kepada internal lembaga pengadilan itu sendiri tetapi surat tersebut berdampak langsung kepada profesi Advokat.

Kedepan untuk menjaga keindependensian profesi advokat dari intervensi lembaga-lembaga lain, maka hal-hal yang terkait dengan profesi advokat mulai dari pengangkatan, sumpah jabatan, pengawasan dan pemberhentian harus diurus, ditangani dan diselesaikan oleh organisasi advokat itu sendiri tanpa adanya campur tangan dari lembaga lain, termasuk dalam hal ini penyumpahan oleh Pengadilan Tinggi terhadap Advokat yang sudah dinyatakan lulus oleh organisasi Advokat harus dihapuskan, penyumpahan tersebut harus dilakukan oleh lembaga organisasi advokat itu sendiri. Tidaklah logis jika sesama aparat penegak hukum (Advokat, Hakim, Jaksa dan Polisi) dimana kedudukannya setara diambil sumpahnya oleh aparat penegak hukum yang lainnya.

\section{PENUTUP}

Memahami keberadaan kedudukan, fungsi dan wewenang advokat, dalam implementasi kebebasan (independensi) dalam menjalankan profesinya sebagai penegak hukum, diperlukan kejernihan dan berfikir komprehensifitas dalam kerangka penataan sistem hukum nasional secara terpadu.

Pada tataran kedudukan, fungsi dan wewenangnya, profesi advokat sebagai nobille officium, memiliki fungsi yang sangat strategis dalam menciptakan sistem peradilan yang baik guna menciptakan suatu kepastian dan keadilan serta kemanfaatan

Wewenang yang diberikan advokat dalam UU No. 18 Tahun 2003 yaitu mengeluarkan pendapat atau pernyataan dalam membela perkara yang menjadi tanggung jawabnya di dalam sidang pengadilan dengan tetap berpegang pada kode etik profesi dan peraturan perundang-undangan. Wewenang advokat tersebut sangatlah umum, 
sehingga memerlukan kewenangan khusus yang diatur dalam Undang-undang advokat itu sendiri.

Pada gilirannya ternyata independensi profesi advokat masih belum sepenuhnya independen, karena masih adanya campur tangan dari lembaga peradilan ke dalam profesi advokat. Untuk itu ke depan dalam rangka memberikan keindependensian profesi advokat dalam sistem peradilan di Indonesia, maka profesi advokat diberi kewenangan yang luas, mulai dari rekrutmen anggota, pengangkatan, penyumpahan, pembinaan dan pengawasan harus dilakukan oleh profesi advokat itu sendiri. Sehingga profesi advokat betul-betul bebas dan mandiri bebas dari campur tangan lembaga lembaga lain termasuk didalamnya adalah peradilan. Oleh karena UU No. 18 tahun 2003 tentang Advokat paling banyak dilakukan uji terhadap UUD 1945 ke Mahkamah Konstitusi (MK) dan masih adanya pasal-pasal yang tidak mendukung keindependensian profesi advokat maka diperlukan untuk merevisi atau merubah UU No. 18 Tahun 2003.

\section{DAFTAR PUSTAKA}

\section{Buku:}

Fadjar., A. Mukthie, 2003, Reformasi Konstitusi dalam Masa Transisi Paradigmatik, Malang: In-TRANS

---------, 2004, Tipe Negara Hukum, Malang: Bayu Media dan In-TRANS

-----------, 2009, Mahkamah Konstitusi sebagai Pelaku Kekuasaan Kehakiman, Bahan Kuliah Program Doktor, Fak. Hukum Univ. Brawijaya.

Harahap, Chaeruman, 2003, Merajut Kolektifitas melalui Penegakan Supremasi Hukum, Bandung: Citra Pustaka Media.

KadafI, Binziad dkk, 2002, Advokat Indonesia Mencari Legitimasi, PSHK.

Henry, Camplell Black, 1991, Lawyer menurut pengertian yang dimuat dalam "Black Law Dictionary"

Panjaitan, Hinca "Fungsi dan Akibat Hukum Keputusan Kepala Daerah dalam Melaksanakan Urusan Tugas Pembantuan Dikaitkan dengan Pokok Pangkal Sengketa", Dalam DimensiDimensi Pemikiran Hukum Administrasi Negara, Penyunting SF. Marbun, et al., Yogyakarta: UII Press.

Parson, Talcot, Esei-esei Sosiologi, alih bahasa: S. Aji, Aksara Persada Press, tanpa tahun

Poerwadarminta, W.J.S., 1987, Kamus Umum
Bahasa Indonesia, Jakarta: Balai Pustaka.

Koehn, Daryl, 2000, Landasan Etika Profesi, Yogyakarta: Kanisius.

Lev, Daniel S., Social Movement, Contitusionalism and Humaqn Rights, in Daniel S. Lev, 2000, Legal Evolution and Political Autherity in Indonesia. Selected Essays. Hugue, London, Boston: Kluwer Law Interrnasional

Lawrwnce, M. Freidmen, 2001, American Law An Introduction, Terjemahan Wishnu Basuki, Jakarta: Tata Nusa.

Wisnobroto, A1, 1997, Hakim dan Peradilan di Indonesia dalam Beberapa Aspek Kajian, Yogyakarta: Universitas Atma Jaya.

Winata, Frans Hendra, 1995, Advokat Indonesia, Citra, Idealisme dan Keprihatinan, Jakarta: Sinar Harapan.

Sajiono, 2008, Memahami Beberapa Bab Pokok Hukum Administrasi, Yogyakarta: Laks Bang Pressindo.

Shimon Shetreet, 1985, Judicial Independence; New Conceptual Demintions and Contemporary Challenges", dalam Shimon Shetreet and J. Deschenes (eds) Judicial Independence (Netherlands: Martinus Nijhoff Publisher.

Soekanto, Soerjono, 1977, Sosilogi suatu Pengantar, Jakarta: Yayasan Penerbit Universitas Indonesia.

Ndraha, Taliziduhu, 2005, Kibernologi sebuah Kontruksi Ilmu Pemerintahan, Jakarta: Rineka Cipta.

Lewis A Coser and Bernard Rosenberg, Sociolocal Theory, A Book of Readings, 4 th. Edition, Mac Millon, New York, 1976, (hasil terjemahan bersama tugas mata kuliah sanksi dan Kepatuhan Hukum

Krisharyanto, Edi. (2007). "Profesi Advokat dalam Penegakan Hukum", Ringkasan Disertasi Program Doktor Ilmu Hukum Program Pasca Sarjana Universitas Airlangga Surabaya.

Taufiq, M dan Moegono, 2007, Moralitas Penegak Hukum dan Advokat "Profesi Sampah", Surabaya: Temprina Media Grafika.

Zen, Patra M., 2008, Dasar-dasar Peran Mulia Advokat, Membaca Daniel S. Lev (edisi khusus). Jentera Jurnal Hukum, (edisi khusus)

\section{Undang-Undang:}

Republik Indonesia, UUD Negara Republik Indonesia 1945 dan Perubahannya

Republik Indonesia, UU No. 14 tahun 1970 
tentang Ketentuan-Ketentuan Pokok Kekuasaan Kehakiman.

Republik Indonesia, UU No. 4 Tahun 2004 tentang Kekuasaan Kehakiman

Republik Indonesia, UU No. 8 Tahun 2004 tentang Perubahan atas UU No. 2/1986 tentang Pengadilan Umum
Republik Indonesia, UU No. 9 Tahun 2004 tentang Perubahan atas UU No. 5/1986 tentang Pengadilan Tata Usaha Negara

Republik Indonesia, UU N0. 18 tahun 2003 tentang Advokat

Kode Etik Advokat 